\title{
How to know about waters? Finnish traditional knowledge related to waters and implications for management reforms
}

\author{
Tero Mustonen · Noora Huusari
}

Received: 26 May 2020/Accepted: 4 September 2020/Published online: 16 September 2020

(C) The Author(s) 2020

\begin{abstract}
Finnish lakes, rivers, the Baltic and wetlands-our aquatic ecosystems-are surveyed, assessed and studied using natural sciences and ecological data. We argue that this approach is leaving out a key repository of information-the traditional knowledge of waters. By reviewing aspects, qualities and depth of knowledge across Finland from mid-boreal ecosystems in Eastern Finland to large Saimaa lake system to Western Finnish lakes we demonstrate a potentially reformative approach to aquatic assessments. Cultural indicators, baseline data from oral histories, linguistic diversity and behaviour of species on lakes based on traditional knowledge observations have the potential to greatly enhance our understanding of ecosystem health. Of special importance are the spawning locations of fish known through traditional knowledge, but often ignored by science-based assessments.
\end{abstract}

Keywords Climate change $\cdot$ Ecosystem assessment $\cdot$ Finland $\cdot$ Jukajärvi $\cdot$ Lakes · Längelmävesi · Puruvesi · Traditional knowledge

T. Mustonen $(\square) \cdot$ N. Huusari

Department of Geography and History, University of Eastern Finland, Yliopistokatu 2, 80100 Joensuu, Finland e-mail: tero@snowchange.org

N. Huusari

e-mail: noorahuu@student.uef.fi

\section{Introduction}

Traditional (and Indigenous) knowledge, including biocultural assessments (Maffi 2005; Harmon 1996; Loh and Harmon 2014) and oral history research (MacDonald 2000) have emerged over the past 30 years as "set" mechanisms of braided (Tengö et al. 2014) and multiple-evidence -based ways of understanding ecosystems. These advances have often their historical roots in the North American collaborative management and equity solutions for nature conservation (Berkes 2008). A large body of established methods and literature (see summaries for example in MacDonald 2000, Berkes 2008) exists from those regions, communities and practitioners who have already shared their crucial knowledge in this paradigm.

Yet, much more needs to be done. This is true both in geographical terms and in levels of engaging with these braided knowledges. Large gaps remain. Those areas which have not been investigated respectfully or extensively are located in the non-Indo-European spaces or at their margins. Perhaps one way of summarizing this realisation is that for these areas, most of the historical and ecological information embedded in local knowledge systems contains the potential of major new discoveries of co-produced and co-designed environmental investigations, monitoring and ultimately, solutions.

Therefore in this paper we will explore traditional knowledge of Finnish waters (Lehtinen 2000; 
Mustonen 2014a; Saiha and Virkkunen 1986). Finland remains in many ways an under-investigated geography in terms of boreal, endemic knowledge systems. We believe that the multi-decadal oral history and traditional knowledge co-production which is presented here in detail merits investigation for international readers and offers views on the complexity, layered nuancing and depth of traditional knowledge systems only accessible through a long engagement with the local knowledge holders, on their terms.

In this paper we are mostly focusing on the ethnically and linguistically Finnish population. The Indigenous Sámi people have their own knowledge system, often called Indigenous knowledge (Brattland and Mustonen 2018), which falls outside the scope of this paper. The coastal Swedish population of Finland has mostly maritime and Baltic -associated cultural practices which also fall outside the scope of this paper.

Modern society approaches weather prediction and ecosystem monitoring using scientific and modelling parameters (for example in Rontu et al. 2019). Decision-making at the science-policy interface relies on expert knowledge (Salmi 2000; 2013; Vehanen 2020) that informs a range of governance levels from the international treaties regarding waters into the European Union to national and ultimately the municipality and community levels.

In Finland the recent decades have seen the rise of an orderly discussion and debate between 'user' and citizen science (Gabrys et al. 2016; Turbé et al. 2019) and expert-driven scientific assessments regarding waters (Salmi 2000, 2013; Vehanen et al. 2020). With the advent of smart phones and sophisticated sonar, camera and GPS technologies local people have shared observations of fish catches, water quality, diatomic algae bloom events and many other day-today information pieces regarding lakes and rivers.

For example the Finnish Environmental Institute SYKE founded the JärviWiki ('LakeWiki', www. jarviwiki.fi) service in 2011. Users can upload, comment and share their observations in a wiki-driven open source platform. The site also contains a segment where people can share 'stories and beliefs' associated with a specific water body. JärviWiki allows for sharing of photos, text, videos and other types of information. JärviWiki is a reflection of the larger global steps toward citizen science and engagement in an era of social media and sharing regarding the environment (Turbé et al. 2019).

Our purpose for this paper lies elsewhere. We base our investigation on the premise of long cultural continuums, breaks and their qualities regarding Finnish water knowledge (Mustonen 2014b). By choosing co-researchers and processes from three distinct lake areas (two in Eastern Finland and a large lake system in the Western part of the country) we hope to demonstrate the qualitative elements and key differences of how waters are known in Finland using multiple knowledge streams.

Most of the materials reviewed and investigated can be called traditional ecological knowledge (Berkes 2008). Mustonen (2014a) has referred to this type of knowledge as 'endemic,' highlighting the slow evolution and adaptation of specific knowledge associated with a lake, river or a marshmire in Finland as opposed to generalized knowledge. It can be also gendered (Huusari 2020). Traditional ecological knowledge (TEK) work also differs from classical anthropology due to the agency. In TEK work the author and interpreter are from the local knowledge context. The analytical interest is not for the purposes of description or outside classification. Rather the main points of work rest on an understanding of a situated (Lehtinen 2000) knowledge.

Our central mission is built on an understanding that cultural indicators (Harmon 1996; Loh and Harmon 2014), baseline data from oral histories (Mustonen 2013), linguistic diversity (Maffi 2005) and behaviour of species on lakes based on traditional knowledge observations have the potential to greatly enhance our understanding of ecosystem health. If they are joined in a respectful way with consented cooperation alongside expert knowledge, the knowledge of the ecology of a waterbody may be greatly enhanced. This has potent applicability in monitoring, adaptation, conservation and restoration activities.

Even with the advent of JärviWiki and other voices in society calling for more shared and diverse knowledge streams the ultimate power of administering the waters (for example for licencing, environmental impact assessments, regulation and so on) has been firmly fixed in the institutional science-policy framework. This will most likely continue to be the case.

By demonstrating a range of examples across midto southern boreal catchment areas and traditional ecological knowledge situations, or in short by 
presenting Finnish knowledge in its heterogeneity, we wish to enter into a rigorous debate on how to refer to the 'real', lived-knowledge situation on the lakes. What is missing from the power-associated sciencepolicy framework today is the positioning of the present change into a long historical continuum (Nunn and Reid 2015) that would contain multiple ecological indicators (fish, bird, insect, plant species, water levels and quality, ice and snow, special events) and human knowledge (oral histories, catch diaries, communitybased observations, catch locations and changes). Inclusion of these braided, divergent and convergent observations and knowledge streams also will address an often silenced and dismissed element in the Finnish water assessments-equity.

We do not position any knowledge to be inherently 'wrong' or 'right'. Instead our open inquiry is resting on the diverse understanding that Finnish lakes, rivers and wetlands have been and continue to be open socioecological systems. Truthful discourses on a lake have to be read in relationship to formalized power (Johnson et al. 2015), distance and capacity of a human community to be able to observe and act (Huntington et al. 2017) and finally the surviving elements of cultural, often 'endemic' (Mustonen 2014a) knowledge of a place (Berkes 2008; Johnson et al. 2015).

\section{Materials and methods}

In the present study we have chosen two relatively large lakes (Puruvesi in the east and Längelmävesi in the west) as well as one smaller lake, Jukajärvi, to scale the observations and determine differences and convergences across geographical and ecological gradients in Finnish traditional knowledge (Fig. 1). We believe this sampling of three distinct lakes will offer enough variation and context to have a potential to be applied elsewhere. By comparing the elements of knowledge, how change is perceived and knowledge contextualized.

One of the authors has been working in two of the locations for over 15 years as a field researcher (geographer) and a professional fisherman. In one case (Jukajärvi lake) he has been working as a researcher in a large ecological restoration project that began in 2010. The other author has been completing her Masters thesis analysing and

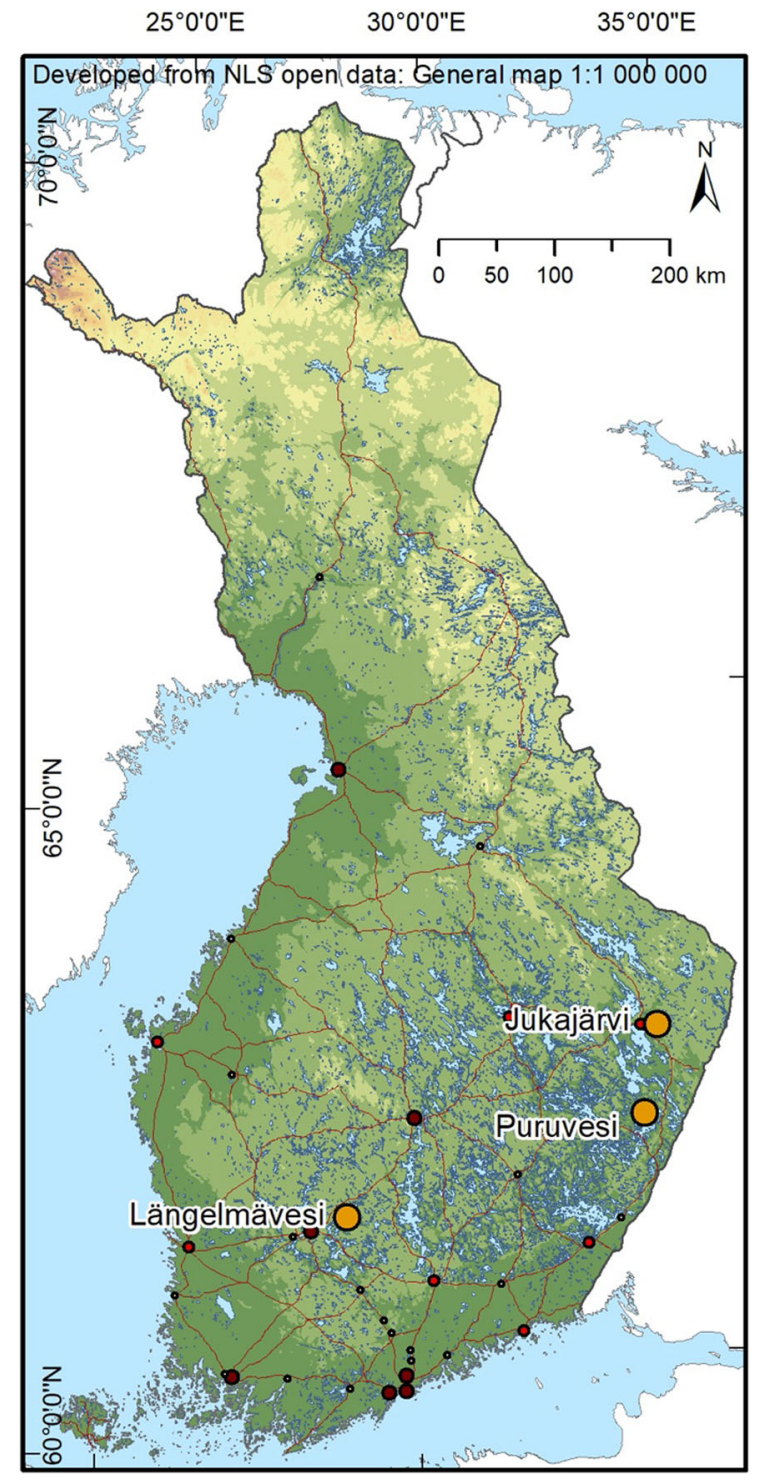

Fig. 1 Research lake locations in national scale, Finland. Map: Johanna Roto, 2020

investigating the elements of Finnish traditional ecological knowledge in relationship with waters (see Huusari 2020). She has been surveying and positioning archival and literature material into a coherent overall scaling of elements of Finnish knowledge, including gendered and bodily aspects.

The overarching method for the inquiry is geographical variation and cohesion (Lehtinen 2000; 2012) across Finland on how traditional knowledge related to waters manifests. We are also using narrative analysis (Cortazzi 1993; see also Lieblich 
et al. 1998) when applicable to highlight examples of traditional knowledge in discourse.

Another key analytical indicator is the survival or loss of traditional knowledge as a communal enterprise (Mustonen 2009). Each case will be investigated to understand what kind of knowledge is seen to be relevant in a particular context especially from the perspective of the knowledge holders. We lead the investigation with Lake Längelmävesi and associated water bodies and then elements of comparative discussions are drawn from the two other case study lakes in Eastern Finland (Puruvesi and Jukajärvi).

More precisely we analyse together elements of traditional knowledge (individual and communal), example indicators of aquatic ecosystems (currents, ice, snow), rate of observations (daily, seasonal), special events in history (baselines 1700-2020), traditional weather forecasting and climate change, key species and their distribution, abundance and variation, relationship to industrial practices (trawling on a lake) and linguistic diversity (Maffi 2005) linked with aquatic diversity.

\section{Längelmävesi}

Längelmävesi (Fig. 2) is a lake located in Western Finland on the eastern side of river Kokemäenjoki catchment area (Hölli 2010; Söderholm et al. 2018). The area of the lake is around 133 square kilometres (Hölli 2010 diverges and says 177 square kilometres by including Koljonselkä into the total) making it the 36th largest lake in Finland ("Greater Längelmävesi" including all inter-connected lakes has a territory of 410 square kilometres in Söderholm et al. 2018). The catchment area is 2180 square kilometres. Maximum depth is 59 meters with an average depth of 6,8 meters. Due to the large number of islands (731) the lake has many separate parts (selk $\ddot{a}$ in Finnish). The lake is central as a freshwater source in the region (Bilaletdin et al. 2010).

Historically a 'greater' Längelmävesi existed. It was connected with lake Roine through the river Sarsanvirta. During a high water flood in 1604 a new outflow river formed as a result of erosion, called Kostianvirta that flows into Mallasvesi lake (Tikkanen 2002; Wallin 2018). This is the most recent natural change in a water system in Finland. This lowered the Längelmävesi water level 2-3 meters, created a new outflow and Iharinkoski was formed (Pirkanmaan luonto 1987; Wallin 2018). Additional change happened when the channelling works on Kaivanto burst and lowered the water level another meter in Längelmävesi in 1830 (Tikkanen 2002). This also dried Iharikoski permanently. These water level changes created a number of smaller lakes which had been a part of Längelmävesi before the alterations and over 30 square kilometres were laid bare (Tikkanen 2002).

Some large floods have been recorded. In 1899 waters rose $57 \mathrm{~cm}$. The 1924 flood is known locally as "valapaton tulva" (Flood of the Oathbreaker). The earliest arrival of lake ice on record is on 2nd November 1941, and the latest has been recorded on 28th January, 1930. Earliest ice break-up in the records is on 15th April 1921 and latest on 26th May, 1941. Maximum thickness of ice ever recorded was $77 \mathrm{~cm}$ in March 2003 (Pirkanmaan luonto 1987).

Present-day main drivers of ecological change result from human settlement and agriculture (59\%) that cause nutrient runoff into Längelmävesi (phosporous and nitrogen) (Hölli 2010: 29). The presence of mercury in the fish was detected in 2012. Hölli (2010: 24) indicates that the authorities are classifying the water quality of Längelmävesi to be "good". Main point polluters include the Orivesi and Sahalahti waste water plants and fertilizer runoff from agricultural fields (Hölli 2010: 58). The lake is considered to be "unregulated" (Hölli 2010) even though Kokemäenjoki river hydrodams prevent access to the sea.

In the case study for Längelmävesi lake we are investigating oral histories of a professional fisherman, small-scale farmer Kalevi Vierikka (1928-2013). Vierikka was born into a family of 18 children in the first part of the 20th century and grew up seining, fish trapping, gill netting and long-lining on the lake. He started his professional fishery in mid1940s. His family used to have over 100 fish traps on the Längelmävesi lake. His main fishing area has been the Ponsanselkä part of the lake (Hölli 2010).

Vierikka grew into a traditional culture of the Häme region by mastering the local dialect, ways of knowing and relations with the lakes around him as an unbroken cultural practice. Between 2002 and 2012 the first author of this paper (Mustonen) fished with Vierikka in the winter, recorded oral histories with him and made field visits around Hukinniemi cape and the island where Kalevi had been fishing all his life. We can call him a cultural Elder from his home region. 


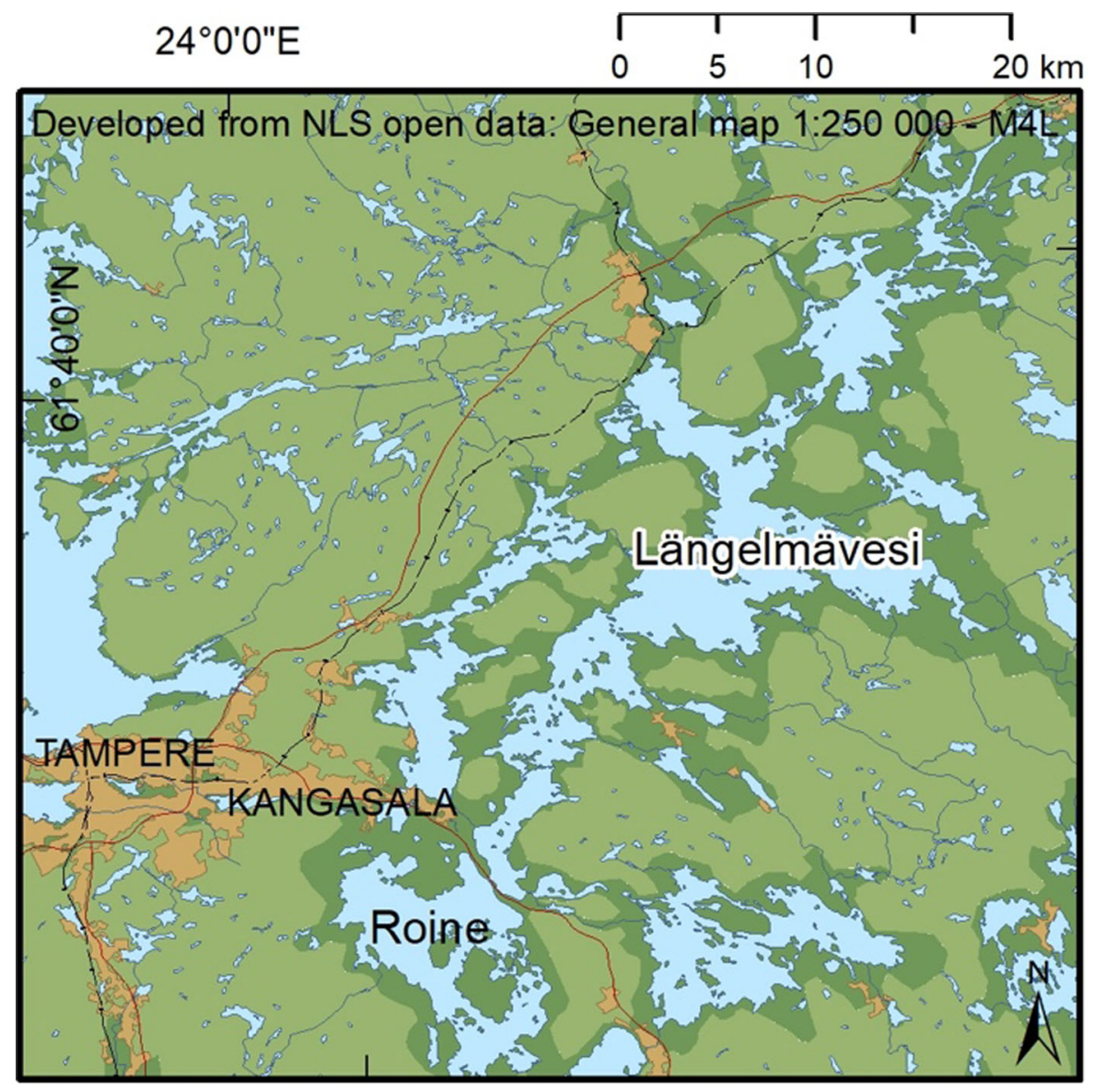

Fig. 2 Längelmävesi lake, Finland. Map: Johanna Roto, 2020

For the purposes of this paper we are using two views into the ways Kalevi knew Längelmävesi lake and the surrounding ecosystems. First we document and present examples of how traditional knowledge looked in Kalevis socio-ecological system. This includes place name -based reflections, traditional weather prediction, local beliefs, lore and deep knowledge.

Secondly we position Kalevis knowledge into a timeline between 1830 and 2010, over 180 years, to note special events that he had marked as significant and interpreted in his context to be worthwhile to think about, know and reflect on. These include memories of large-scale ecological change (the bursting of the Kaivanto channel 1830, droughts, large storms), climate and weather change events, especially storms and special fishery catches (500 kgs of Common Bream in 1941). These knowledge items have been summarized into charts in the attached. Additional sourcing has been included from literature of the oral histories around Längelmävesi (Virtaranta 1950) and from two other professional fishermen and their oral histories (Sairiala, Hakala) to assess and position Kalevis observations in comparison.

\section{Jukajärvi}

Jukajärvi lake (Fig. 3) is a 218 hectare smallish lake located in the Vuoksi catchment area of Saimaa, more specifically in the mid-boreal area of Pielisjoki catchment (Mustonen and Mustonen 2013). Average depth is 3,77 meters and at the deepest point is 17 meters. Perch, northern pike and pikeperch constitute average catches on the lake. The catchment area of the lake is roughly 9000 hectares.

Jukajärvi has been lowered by humans three times in history: in $1760 \mathrm{~s}, 1863-1865$ and finally in 1959-1963. These actions were made to increase the 


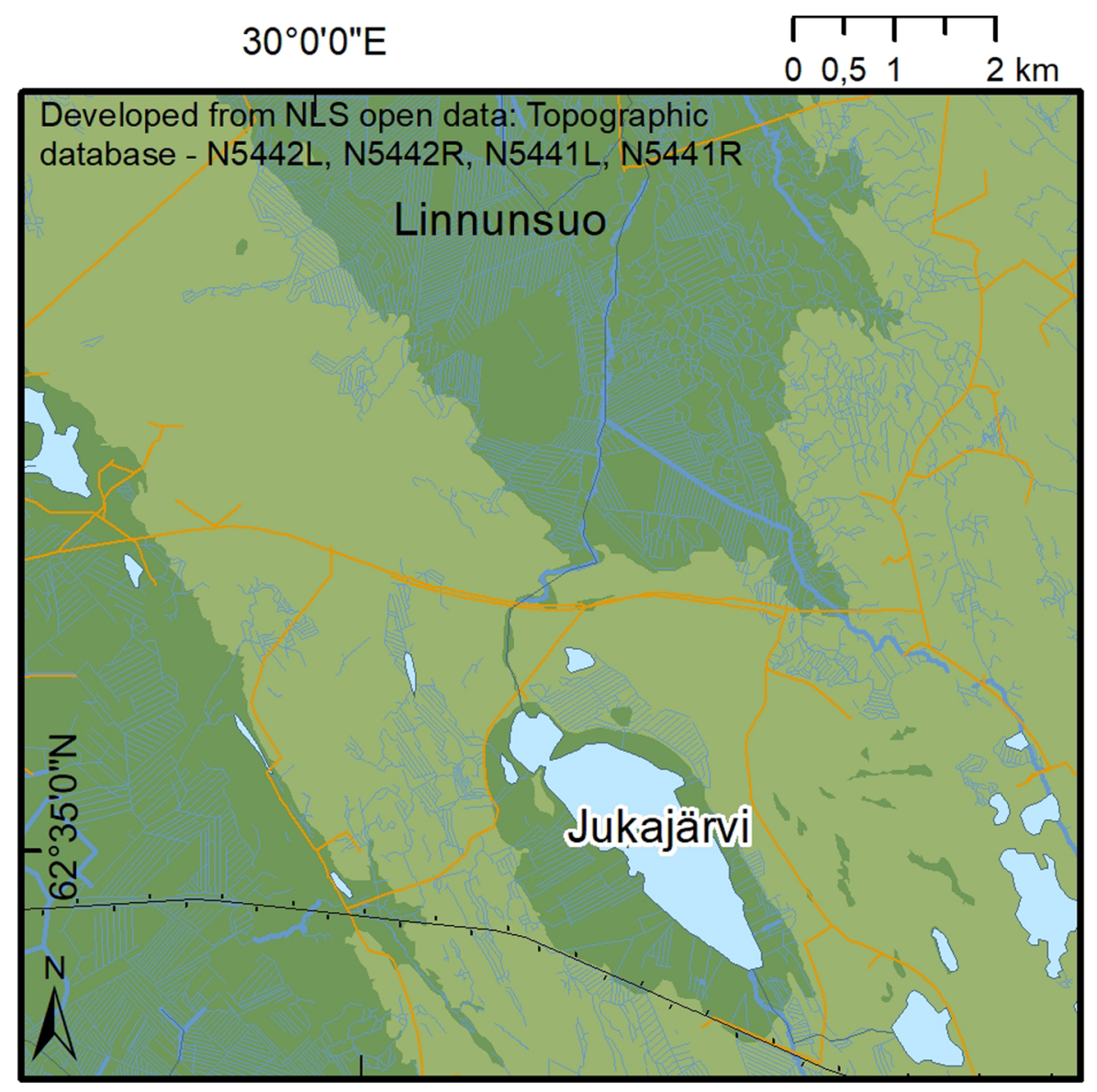

Fig. 3 Jukajärvi lake, Finland. Map: Johanna Roto, 2020

available space for agriculture and fields. Unbeknownst to the local villagers at the time the soils of the Jukajärvi lake are very acidic resulting from postGlacial iron sulphates (Mustonen 2014b). The lowering and significant human alterations to the lake and catchment area have produced a number of ecological problems, including repeated fish deaths in the catchment (Mustonen and Mustonen 2013; Kiiskinen 2013; Tossavainen 2014), heavy loading of metals, especially Iron-Fe and organic loading resulting in partial eutrophication process for the lake (Fig. 4).

In this study Jukajärvi represents a heavily altered and modified water body since $1760 \mathrm{~s}$. We assess a decade-long documentation of traditional knowledge and oral histories from the lake and catchment that were documented as a part of the restoration baseline information (see Mustonen 2013; Mustonen and Mustonen 2013; Huusari 2020; Tossavainen 2014). The co-researchers in the case of Jukajärvi are household and subsistence fishermen who either live or occasionally visit the lake. In this case we seek to understand and contextualize a large number of traditional knowledge entries over a decade and deduce results from an altered ecosystem as restoration activities are planned and executed based on both science and traditional knowledge (Kiiskinen 2013, Tossavainen 2014). Of special interest is the discovery of the brook lamprey in the catchment area and its importance as an ecological indicator (Mustonen and Tossavainen 2018).

\section{Puruvesi}

Puruvesi (Fig. 5) is a part of the larger Saimaa lake system, one of the largest in Europe. All in all it is over 41,000 hectares (416 square kilometres). The catchment area is rather small at 1000 square kilometres. Average depth is 8,76 meters and the deepest part is 61 


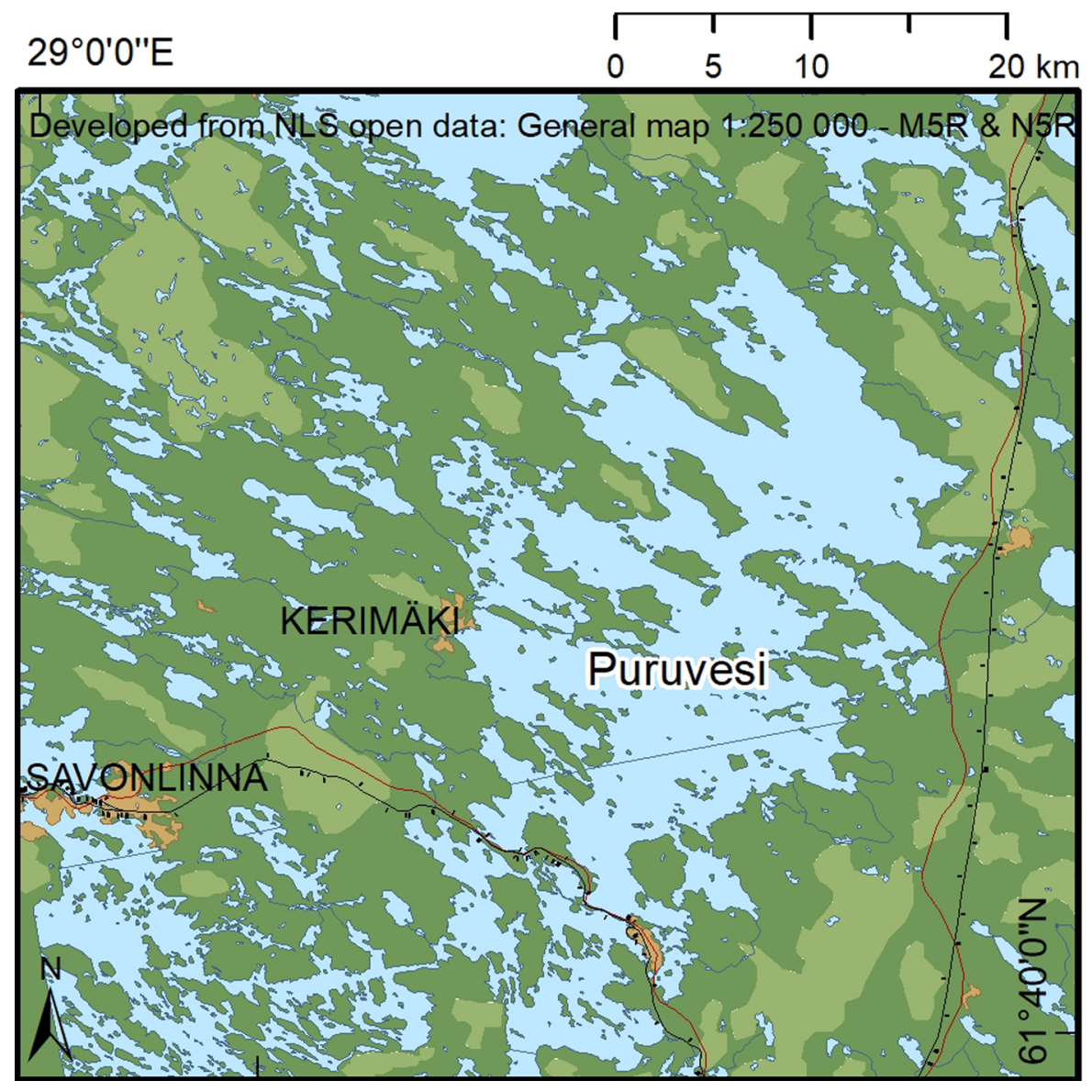

Fig. 4 Puruvesi lake, Finland. Map: Johanna Roto, 2020

meters. Over 860 islands are located on the lake. It is located in the Kitee and Savonlinna city territories even though the lake is situated rurally in the village of Kesälahti and Kerimäki. It is in a rather good ecological condition and highly oligotrophic (Mustonen 2014a) despite the first algae blooms that have started to manifest since early 2010 s. Many fish species including vendace, whitefish, trout, Atlantic lake-bound salmon, smelt, ide, Arctic char and grayling live naturally in the lake. Fourhorn sculpin (Myoxocephalus quadricornis) and the freshwater Saimaa seal (Phoca hispida saimensis) are relics from a more maritime character of the lake and its ancient connection with the Baltic. Puruvesi is a Natura 2000 area as designated by the EU.

Puruvesi is the home of the traditional vendace seining, especially winter-time fishery (Mustonen 2014a). Our discussion of aspects of traditional knowledge from Puruvesi rest on literature review (with summaries including Pennanen 1979, 1986; Mustonen 2009; 2014a; b; Pakarinen 2013; Huusari 2020), collection of oral histories and observations between 2005 and 2020, and the surviving communal elements of this knowledge as an exception in the rather atomized society of Finland. Seining records begin in $1300 \mathrm{AD}$ and the fishery has received a number of accolades including an EU Geographical Indicator and national intangible culture status. Fishermen have successfully defended the lake against trawling fleets advocated by the state. Varied elements of traditional knowledge and its applicability emerge from the stocking programme of vendace that was implemented as a response to loss of vendace stocks in $1970 \mathrm{~s}$ and $1980 \mathrm{~s}$. Bodily knowledge of a lake (Huusari 2020) highlights the nuances and details of how Puruvesi is known by the local fishermen. 


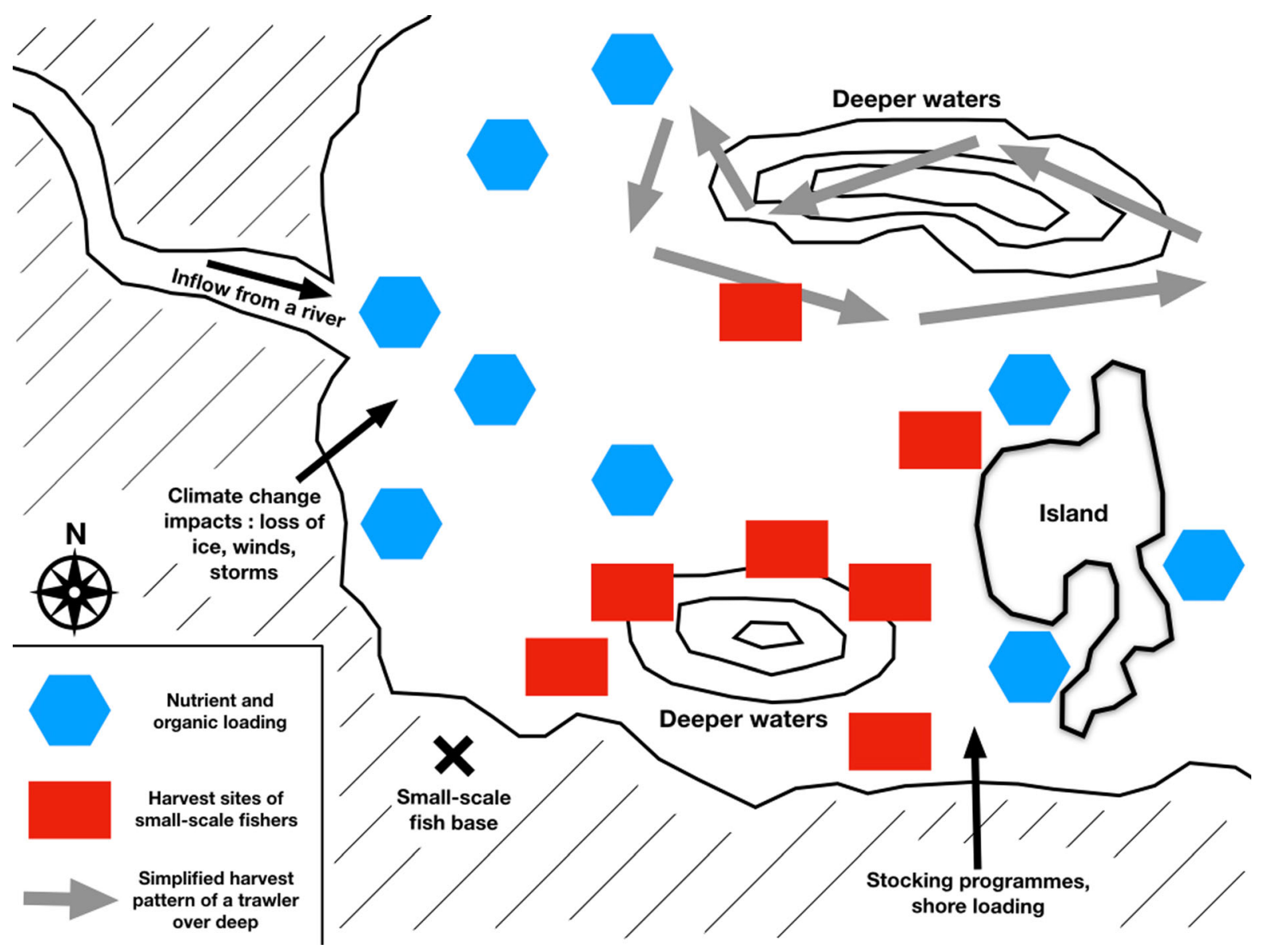

Fig. 5 Multiple drivers of change summarized on a boreal lake in relationship to small-scale fisher uses. Harvesting areas (red squares) mark the availability of spots around the deeper parts. They have occasional conflict with industrial trawling (arrows). Nutrient and organic loading arrives via rivers (as per in upper left corner), marked as blue sextagons. It accumulates in the shallows, often where the spawning areas of fish are located. Stocking programmes (arrow on the right), designed to increase "productivity", introduce both non-native species and genetic

\section{Results}

The results of our comparative investigation into Finnish traditional knowledge are presented in a dialogic manner. First the primary results of Längelmävesi set the scene. Then lake Jukajärvi (damaged and recovering ecosystem) and Puruvesi (a rather pristine communal fishery) are looked at for divergence and convergence of practice, knowledge and responses to drivers inside the lakes and outside forces (such as weather and climate change, eutrophication, trawling). stocks into the natural lake without any screening. Shore loading increases nutrient loading. Resulting eutrophication favours coarce fish and fish that thrive in warmer waters on the expense of the salmonids. Climate change impacts have started to alter the lake condition. Main drivers include drought, strong winds and new storms in summer as well as loss of cryosphere conditions, i.e. proper ice conditions. Map: Antoine Scherer, 2020

\section{Längelmävesi}

Kalevi Vierikka, our co-reseacher, passed away in 2013. However, his shared knowledge and oral history tapes have been assessed for the purposes of this paper. Vierikka would stake his view of the world by saying often: "humans exist to advance development forwards! And that everybody would have good conditions to live." (Vierikka Oral History Tape). Together with his wife Eeva, Kalevi would often mark how much the culture and society had changed in Finland in 
their lifetimes, especially after the Winter and Continuation Wars.

Kalevi would often stress that in order to know the behaviour of a lake, you would need to know the way the currents and water flow. He had been taught that fish always swam towards the current. The same applied, according to him, to mammals, both domesticated (sheep) and wild (moose, deer) - they always ran against the wind.

Kalevi had learned very traditional fishing practices in his childhood. This included for example wooden hooks made from juniper (Juniperus communis) where smelts (Osmerus eperlanus) were put as bait. This was done in order to catch bottom-dwelling burbots (Lota lota). He says that he learned his weather prediction skills both from experience and from the older people: "I learned everything the hard way and as well discussing with the old people for example from Eräjärvi village." (Vierikka $\mathrm{OR}$ ).

A central component of the way Kalevi acquired his knowledge was based on daily observation of the Längelmävesi lake. One time in the autumn when the ice was still rather thin he had been observing a large school of Common bleak (Alburnus alburnus) through the ice. Based on this he proceeded to set two nets there and caught 17 northern pikes (Esox lucius) and one burbot.

He was able to be successful in catching a large amount of fish by deducing that the pike were after the bleaks. However, Kalevi often wondered why the Common bleak gather and cause "commotion" in September outside the normal spawning time when they come to the Noksioislahti bay. Many mysteries remained in nature that greatly intrigued Kalevi.

Kalevi was connected with the surrounding topographic features in many ways. During oral history work he said that in $1880 \mathrm{~s}$ people did not have last names. One of the hills, Vierikkavuori, a $160 \mathrm{~m}$ tall local high ground, gave the name to the family Vierikka. Additionally he knew the micro-histories of other surrounding islands and places well. For example:

- Halkosaari island was a place where people went for firewood and logs.

- Hohkasuunkari, which was known as Vänninkari. It was used by a local man called Vänni to dry hay for his cows and thus acquired the name based on this man.
- Uhrikallio, a pre-Christian sacrificial place. A rock area which had "an altar and cups in the stone surrounding the altar". Kalevi had visited this former sacred place before it was destroyed for second holiday homes.

- Eräpyhä: A sacred, protected place from the Bronze Age, which is nationally known, on the Eastern shore of lake Längelmävesi. Kalevi said that local oral histories had indicated people came there for "festivities" and "dances".

After the visit to Uhrikallio site Kalevi had found out a similar sacrificial stone with the cups in the rock from his shore. Based on his own interpretation it was a similar "sacrificial stone" as in the Uhrikivi area. Kalevi, born in 1920 s, was of the last generation that was immersed in the customary and traditional beliefs and their remnants of Elders born in $1850 \mathrm{~s}$ and before. He found the sacrificial sites to be of great interest in his home area.

The deep knowledge of the lake was also reflected in the omens and visits that prophesized future events. Kalevi and his wife Eeva would convey a story of a large "salmon/trout" they caught. It was usually a very rare event (Virtaranta 1950: 243). One of the older people in the village said that this means death will visit soon (present also in Virtaranta 1950). The following night Kalevi's uncle passed. Northern pike was thought to be in a special role as the 'guardian' of the lake (in Virtaranta 1950: 335). Other indicators between the invisible world and human realm included for example cuckoo (Cuculus canorus) and Black woodpecker (Dryocopus martius) as messanger birds. Also dreams showed things to come.

In weather-related knowledge Kalevi had some endemic (Mustonen 2014a) communal concepts. Karmutuuli implied a strong wind that could be used as a marker to calculate the ice break-up. Koiraskuu (a 'male' new moon) implies a bad month ahead. Aureriita is a reflection of the sun on the Western horizon in an arch of clouds. Other fishermen, such as Viljo Hakala (2002) and Esko Tuominen (2002) in their oral histories also confirm the use of the moon as a marker for fishing decisions, pointing to surviving communal knowledge. Water temperature and wind direction are other important indicators for fish movements.

Summarizing Kalevi's traditional knowledge regarding weather prediction markers (Table 1) we 
Table 1 Summary of aspects of weather prediction knowledge by Kalevi Vierikka

Aspects of traditional knowledge

Observations of Kalevi Vierikka

Seasonal round

Meaning/Signifigance

Scale

January

New moon born 'close to the Earth'

New moon born

"Dark moon" in the sky

New moon is "koiraskuu" (male)

February

2nd February (kynttilänpäivä) karmu wind

March

Snow melts on top of the ice

Sometimes no snow at all on ice

Oxygen rich water goes into ice holes

Forest grouse signs for the first time

Last karmutuuli winter in end of March

April

25th April, Day of Markku, nightime frosts

May

New moon born 'close to the Earth'

June to July

Vendace closer to the surface

Storm winds in summer

A fish-scale or thrush breast shaped cloud arises

August

Vendace goes deeper

First frost on wooden bridges

September

Forest grouse signs for the first time (autumn)

Last thunder strikes

First frost

"Iron nights" 11th to 13th August frost-free

First snowfall

October

Rock is 'sweating'

Grass has a drop of water on top

Windows are frozen

Warm weather in October

Club rush (Scirpus) has a frozen 'ball' at stem

Water tip on a Norway Spruce branch

Muskrat collects reeds and branches

Water levels low in Autumn

Water levels high in Autumn

November to December

First snowfall

First snowfall
Mild winter

Fish will bite and move 4-5 days after

Fish will not bite or move

A bad month will follow

77 days to ice breakup (around 22nd April)

Water accumulates on spring ice

Duration for the whole winter

Stimulates fish with oxygen water

Six months to the first snowfall in Autumn

Six months to the karmutuuli in Autumn

No blueberries in the coming summer

Mild summer

Season

Nets set at the $+8 \mathrm{C}$ pycnocline

Weeks

Fish will start moving

Raill will follow

Short term

Short term

Nets set at 27 meters and deeper

9 weeks before the smaller lakes are frozen over

Short term

Season

Nine weeks to the first snowfall

Season

Nine weeks to arrival of winter

Season

It will rain the next day

No autumn frosts, warm season ahead

Short term

Season

Season

Rain will fall the next day

Short term

Rain will fall the next day

Short term

It will rain water in January

Season

Heavy frosts in February

Season

Season

Four weeks before the main lake is frozen

Short term

Short term

Five weeks to winter

Season

Season

Prolonger ice melt, "ice will be stranded on land"

If forest hare stays 3 days in nest, the snow will stay

Short term

Moose stay put during proper snowfall
Short term 
Table 1 continued

Aspects of traditional knowledge

Forest hare moves around despite snow

Mosquito swarm on fresh snow

Fallen snow melts from larger rocks in the forest

Snow forms mounds

Voles, moles and forest mouse arrive in house

Bullfinch on feeder

December
Snow will not stay

Short term

Snow will not stay

Short term

Snow will not stay

Short term

Snow will not stay

Winter will start and stay

Short term

Season

Frosts will start in 2-3 days

Short term can see it ranges from short-term predictions to seasonal. Central for weather in Kalevis predictions is the role of the moon. It influences the weather, the fish and the seasons ahead. Another crucial marker is the wind, especially the Karmutuuli that has been able to predict ice break-ups and freeze-ups.

A number of animals, including forest grouse (Lyrurus tetrix), forest hare (Lepus timidus) and bullfinch (Pyrrhula pyrrhula) play a role as messengers of changes in weather. Marker days throughout the year are used. Other fishermen (Sairiala 2002) stress how different fish, such as perch and roach have markedly different "zones" in the lake compared to vendace.

The documented changes and observations regarding Längelmävesi (Table 2) span a timeframe of 1830 (channelling of Kaivanto) to 2010 (Kalevi's last year on the ice fishing). The earliest oral history and TEK observations convey memories of the 1830 event, large storms and abundance of certain fish species, such as northern pike (Esox lucius) and smelt (Osmerus eperlanus). The floods of 1899 and 1924 mark large natural events of a "new" Längelmävesi which includes the Channel.

Droughts and ice quality from $1930 \mathrm{~s}$ are the earliest environmental knowledge Kalevi remembered. The arrival of muskrat altered the coastal areas of the lake. Observations from $1930 \mathrm{~s}$ to $1940 \mathrm{~s}$ are reflective of the large commercial fishery in Kalevis family with seines, fish traps and gill netting. One of the marker events is the early disappearance of vendace (Coregonus albula) in 1951 and a strong comeback in $1980 \mathrm{~s}$.
This correlates with Hölli (2010: 42) regarding both vendace stocks and size. Hölli (2010: 42) confirms the " 1985 " boom, who had a reported catch of 46 tonnes (compared with low tonnage landed in previous years). Also Hakala in his oral history refers to "unknown" cycles of vendace (2002) that are hard to explain but do happen. Vendace also follow ice conditions closely-at ice break-up the fish are "on the surface" (Hakala 2002) and later in summer go deeper. These fish can be found up to 60 meters deep in mid-summer to July, and hard to catch when they follow the plankton (Sairiala 2002). Sairiala (2002) links the increase in agricultural run-off with the loss of vendace spawning areas which are "clogged" due to the run-off.

Kalevi and other fishermen (Hakala OR 2002) agree on the impact that stocking whitefish has on natural vendace stocks. Fishermen also distinguish the lake Längelmävesi vendace from the neighboring Pälkänevesi and Mallasvesi stocks and say they operate on "different" cycles (Hakala OR 2002).

Equally relevant for commercial catches is the early boom of pikeperch (Sander lucioperca). We can determine the $1950 \mathrm{~s}$ spawning to be "natural" and the 1980-2000 s fish to have benefited from large stocking programmes (Hölli 2010: 60, Kolari 2018) with sometimes over 100,000 young fish stocked in a lake. Recommendations for $2010 \mathrm{~s}$ included 70,000 individual fish to be stocked annually (Hölli 2010: 93).

According to Kalevi the first really warm, unusual year was during winter 1988-1989. Since then his weather prediction skills were challenged as "everything has changed". 1997 still followed 
Table 2 Summary of weather and ecological change observations by Kalevi Vierikka and documented traditional ecological knowledge and oral histories

\begin{tabular}{|c|c|c|c|}
\hline \multicolumn{4}{|l|}{ Special events and observations } \\
\hline \multicolumn{4}{|l|}{$\begin{array}{l}\text { Kalevi Vierikka and recorded } \\
\text { TEK }\end{array}$} \\
\hline Observation & Meaning & Year & Source \\
\hline $\begin{array}{l}\text { 4th April bursting of the } \\
\text { Kaivanto channel }\end{array}$ & $\begin{array}{l}\text { Original water level } 3 \text { meters higher, } \\
\text { marked on cliff }\end{array}$ & 1830 & Vierikka OR \\
\hline Large storm event & Whole lake in massive waves & 1868 & Virtaranta (1950): 335 \\
\hline $\begin{array}{l}\text { Large and plentiful common } \\
\text { breams }\end{array}$ & Large amounts caught in seines & $1870 \mathrm{~s}$ & Virtaranta (1950): 333 \\
\hline Large amounts of crayfish & $\begin{array}{l}\text { Imported to St. Petersburg, major clean } \\
\text { indicator }\end{array}$ & $1800 \mathrm{~s}$ & Tuominen OR \\
\hline 19-20 kg pikes caught & Large predator fish plentiful & $1870 \mathrm{~s}$ & Virtaranta (1950): 333 \\
\hline $\begin{array}{l}\text { Large storm stopped all boat } \\
\text { travel }\end{array}$ & Whole lake in massive waves & $1870 \mathrm{~s}$ & Virtaranta (1950): 335 \\
\hline Late $1800 \mathrm{~s}$ plenty of smelt & $\begin{array}{l}\text { Smaller smelts which have diminished } \\
\text { since }\end{array}$ & $1880 \mathrm{~s}$ & Virtaranta (1950): 187 \\
\hline $\begin{array}{l}\text { Längelmävesi famous for large } \\
\text { pikes }\end{array}$ & Large predator fish plentiful & 1881 & Virtaranta (1950): 243 \\
\hline Large flood & Waters rose fast & 1899 & Pirkanmaan luonto (1987) \\
\hline $\begin{array}{l}\text { Large flood "of the Oath } \\
\text { Breaker" }\end{array}$ & Waters rose fast & 1924 & Pirkanmaan luonto (1987) \\
\hline Clear, early Autumn ice & $\begin{array}{l}\text { Clubbing of burbot possible, not any } \\
\text { more }\end{array}$ & $1930 \mathrm{~s}$ & Vierikka OR \\
\hline Water levels very low & Warm summers, no rain & $1930 \mathrm{~s}$ & Vierikka OR \\
\hline $\begin{array}{l}\text { Water could not be used for } \\
\text { drinking }\end{array}$ & Dirty waters and very low & $1930 \mathrm{~s}$ & Vierikka OR \\
\hline $\begin{array}{l}\text { Muskrat introduced from } \\
\text { Canada }\end{array}$ & $\begin{array}{l}\text { Ate all reeds and bay plants, affected } \\
\text { spawning grounds }\end{array}$ & $1930 \mathrm{~s}$ & Vierikka OR \\
\hline Major frosts, $-40^{\circ} \mathrm{C}$ & Winter very cold and long & 1939 & Vierikka OR \\
\hline $\begin{array}{l}\text { Great catches with seining for } \\
\text { bream }\end{array}$ & Bream collects around timber floats & 1941 & Vierikka OR \\
\hline There used to be much vendace & Significant local autumn fishery & $1930 \mathrm{~s} ?$ & Vierikka OR \\
\hline $\begin{array}{l}\text { Loss of vendace, eventual } \\
\text { complete end }\end{array}$ & End of fishery, fish gets bigger & 1940-1969 & Vierikka OR \\
\hline Extremely warm spring & Spring work started early & 1948 & Vierikka OR \\
\hline Whitefish stocked & Vendace lost & 1951 & Vierikka OR, Hakala OR \\
\hline $\begin{array}{l}\text { Large catch of pikeperch ( } 8 \text { fish } \\
\text { in } 20 \mathrm{~min} \text { ) }\end{array}$ & Large population of pikeperch & 1951 & Vierikka OR \\
\hline Early snowfall on 17th October & Snow stayed until May & 1952 & Vierikka OR \\
\hline Large catches of pikeperch & Peak years 1950-1960 until 1992 & 1952-1992 & Vierikka OR \\
\hline Major storm in the summer & Biggest storm observed to date & 1960 & Vierikka OR \\
\hline $\begin{array}{l}\text { First European Herring Gulls } \\
\text { arrive }\end{array}$ & New species expansion & $1960 \mathrm{~s}$ & Tuominen OR \\
\hline Water levels very high & Local bridges flooded & 1984 & Vierikka OR \\
\hline $\begin{array}{l}\text { Boom and cycles in vendace } \\
\text { fishery }\end{array}$ & Comeback of commercial stocks & 1981-1985 & Vierikka OR, Hakala OR \\
\hline $\begin{array}{l}\text { Pikeperch dived deep and } \\
\text { stayed at Xmas }\end{array}$ & $\begin{array}{l}\text { Cold start, rest of the winter extremely } \\
\text { warm }\end{array}$ & 1988-1989 & Vierikka OR \\
\hline
\end{tabular}


Table 2 continued

\begin{tabular}{|c|c|c|c|}
\hline \multicolumn{4}{|l|}{ Special events and observations } \\
\hline Mild winter with low snows & $\begin{array}{l}\text { First real warm winter, }+7^{\circ} \mathrm{C} \text { at end of } \\
\text { Feb }\end{array}$ & 1989 & Vierikka OR \\
\hline Liverwort collected 31st March & Plants sprouting early & 1989 & Vierikka OR \\
\hline $\begin{array}{l}\text { Spring break-up has become } \\
\text { earlier }\end{array}$ & Ice free waters in April & 2001-2002 & Hakala OR \\
\hline Ice-break-up 22nd April & $\begin{array}{l}\text { Early ice break-up, as karmutuuli } \\
\text { predicted }\end{array}$ & 1989 & Vierikka OR \\
\hline Warm spring & Ice break up and quality of ice reflected & 1990 & Vierikka OR \\
\hline Stablisation of vendace stocks & Household harvest possible & 1990-2009 & Vierikka OR \\
\hline $\begin{array}{l}\text { Introduction of trawling wipes } \\
\text { out vendace }\end{array}$ & $\begin{array}{l}\text { Trawling collapsed vendace, boom in } \\
\text { smelt on Mallasvesi }\end{array}$ & $1990 \mathrm{~s}$ & $\begin{array}{l}\text { Hakala OR, Sairiala OR, Tuominen } \\
\text { OR }\end{array}$ \\
\hline $\begin{array}{l}\text { Last thunder and karmutuuli } \\
\text { wind ok }\end{array}$ & Winter followed according to prediction & 1997 & Vierikka OR \\
\hline $\begin{array}{l}\text { Waters very low, marked at } \\
\text { Myllykari }\end{array}$ & $\begin{array}{l}20 \mathrm{~cm} \text { lower waters than 'usual', last } \\
1930 \mathrm{~s}\end{array}$ & 1999 & Vierikka OR \\
\hline $\begin{array}{l}\text { Heavy rains between } 4 \text { th-10th } \\
\text { October }\end{array}$ & $164 \mathrm{~mm}$ & 2000 & Vierikka OR \\
\hline Late freeze-up, 11th January & Warm winter & 2000 & $\begin{array}{l}\text { Vierikka OR, Tuominen OR, Hakala } \\
\text { OR }\end{array}$ \\
\hline $\begin{array}{l}\text { Summer and autumn very } \\
\text { special }\end{array}$ & $\begin{array}{l}\text { Extreme warmth and drought, difficult to } \\
\text { sleep }\end{array}$ & 2001 & Vierikka OR \\
\hline $\begin{array}{l}\text { Extreme winds and a storm } \\
\text { never seen }\end{array}$ & New weather extremeties for November & 2001 & $\begin{array}{l}\text { Vierikka OR, Sairiala OR, Tuominen } \\
\text { OR }\end{array}$ \\
\hline Summer drought & Waters very low & 2002 & Hakala OR \\
\hline $\begin{array}{l}\text { Large thunderstorms stop } \\
\text { vendace }\end{array}$ & $\begin{array}{l}\text { Vendance reacts to thunder storms by } \\
\text { disappearing }\end{array}$ & $1990 \mathrm{~s}$ & Tuominen OR \\
\hline Water quality "bad" & Build-up of coastal cabins, land use & $1960-2000$ & Vierikka OR \\
\hline $\begin{array}{l}\text { Loss of water quality, } \\
\text { eutrophication }\end{array}$ & $\begin{array}{l}\text { Large-scale agricultural and waste runoff, } \\
\text { spawning effect }\end{array}$ & $1980-2000 \mathrm{~s}$ & $\begin{array}{l}\text { Vierikka OR, Hakala OR, Sairiala OR, } \\
\text { Tuominen OR }\end{array}$ \\
\hline $\begin{array}{l}\text { Expansion of roach in surface } \\
\text { waters }\end{array}$ & Warmer temperatures & 2002 & Tuominen OR \\
\hline $\begin{array}{l}\text { "Eternal spring and eternal } \\
\text { autumn" }\end{array}$ & Loss of proper seasons & 2002 & Vierikka OR \\
\hline "Climate has become anew" & Weather systems out of place & 2000-2002 & Sairiala OR \\
\hline Extremely early freeze up & Lakes froze in October & 2002 & $\begin{array}{l}\text { Vierikka OR, Tuominen, OR, Hakala } \\
\text { OR, Sairiala OR }\end{array}$ \\
\hline Lack of snow activates fish & $\begin{array}{l}\text { Ice allows more light through, fish more } \\
\text { active }\end{array}$ & $2000 \mathrm{~s}$ & Tuominen OR \\
\hline $\begin{array}{l}\text { Syringa lilac flowers in early } \\
\text { June }\end{array}$ & Three week shift to earlier & $2000 \mathrm{~s}$ & Vierikka OR \\
\hline $\begin{array}{l}\text { Accumulation of fishing rights } \\
\text { to only a few }\end{array}$ & $\begin{array}{l}\text { Access prevented to small-scale } \\
\text { professionals }\end{array}$ & 2000 & Sairiala OR, Tuominen OR \\
\hline Lesser black-backed gull lost & $\begin{array}{l}\text { Numbers diminishing especially in the } \\
\text { past } 20 \text { years }\end{array}$ & $1990-2000 \mathrm{~s}$ & Tuominen OR \\
\hline
\end{tabular}


predictable events including the karmutuuli as a marker. Then in $2000 \mathrm{~s}$ droughts and warm winters led Kalevi to make the observation that "seasons have been lost".

Kalevi and other fishermen (Hakala OR, Sairiala OR, Tuominen OR) criticize the use of trawling on these linked lakes (especially Mallasvesi). They saw this affecting the fish negatively, especially the vendace stocks, when the individual catches from trawling are up to $900 \mathrm{~kg}$ at a time. Seining, gill netting and fish traps are perceived to be "lake gear" and trawling is seen to damage the stocks due to the ability of trawlers to catch large amounts of fish. Trawling according to Tuominen (2002) triggered a boom in smelt as the smelt eats young vendace and the stocks could rebound after these impacts from 1992 to 2001.

Trawling was allowed on the neighbouring Mallasvesi in $1990 \mathrm{~s}$ through the fishing rights associated with mantals, privately owned portions of lakes. This created equity issues amongst the fishermen due to ecological and stock impacts from the practice of trawling, and the inability of officials to regulate privately owned portions of the lakes. Overall the small number of permits allowed for the professional fishery has remained a problem as perceived from the view point of the small-scale fisher.

Sairiala (2002) as well as Kalevi observed the decline in water quality and increased eutrophication on Lake Längelmävesi and surrounding waters. Changes in land use due to farming and increasing numbers of cabins in the area are seen to be the drivers of this change. Tuominen (2002) associated increased eutrophication on Längelmävesi with the waste water releases from the Saarioinen food plant (where especially chicken was produced) from $1980 \mathrm{~s}$ onwards. He perceived this to have increased the loading of nutrients and phosporous into the lakes Roine, Mallasvesi and Längelmävesi.

Positioning Kalevis observations with official data (Kolari 2018: 40) the early $2000 \mathrm{~s}$ are in agreement especially regarding the warm summer temperatures. Also the observations of strong pikeperch catches match in part the official statistics from late $1950 \mathrm{~s}$ to early $1960 \mathrm{~s}$ (Kolari 2018: 36). However Kolari (2018: 37) says that nationally the strongest years were in the early part of $1950 \mathrm{~s}$ based on the positive impact of warm weather on the stocks. Eutrophication observations correspond to the water sampling results.
Jukajärvi

An element that links lake Jukajärvi with Längelmävesi is the presence of long-term human alteration and influence (in $1760 \mathrm{~s}$ from Jukajärvi, in 1830 from Längelmävesi) (Kiiskinen 2013, Tossavainen 2014). Agriculture is not the main culprit-rather the lowering of the lake is, with similarities to the situation in Längelmävesi. Of special note is the soil chemistry in the catchment area. The loading of Iron (Fe) reached up to 40 tonnes per year to the lake at its peak (Kiiskinen 2013).

For this research over 30 subsistence and household fishermen were documented for their observations (Mustonen and Mustonen 2013, Huusari 2020). We can summarize that the knowledge of these nonprofessional fishermen is occasional, focusing on events of significance for individuals. Land ownership and knowledge exchange is on an individual basis even though both the villagers of Alavi (closest community) and summer home owners are exchanging their experiences irregularly (Mustonen and Mustonen 2013).

The human-caused lowering of the lake in 1959 emerged as a key turning point for the lake health. Documented observations indicate that the sandy bottom turned to "mud", fish stocks perished, water levels went down and the change was seen to penetrate "all of the system" (Huusari 2020). The loading of organic matter coincided with national programmes that ditched most of the catchment area marshmires for forest production (Mustonen and Mustonen 2013).

On Lake Jukajärvi as Huusari (2020) points out locally clean water has implied acidic waters causing even fish death, i.e. highly toxic waters occurring occasionally. The universality of 'clear water' as an indicator is therefore challenged in this localized context.

\section{Puruvesi}

Puruvesi is similar to Längelmävesi in that both are large lakes in Finnish context. In the assessment of traditional knowledge we focused on an oral history documentation (2005-2020), literature review (Pennanen 1979, 1986; Mustonen 2009, 2014a; Pakarinen 2013) and participant observation (as a member of a seining crew 2005-2020). 
The key traditional knowledge from Puruvesi is associated with the communal seining that dates back to at least $1300 \mathrm{AD}$. Today the seining is professional and targets vendace (Coregonus albula). TEK in Puruvesi is also internationally recognized and protected under the EU Geographical Indicator and the national intangible cultural status (Huusari 2020).

Out of all cases in this inquiry the Puruvesi TEK is an example of unbroken, communal knowledge production spanning centuries around one lake. Huusari (2020) says that the knowledge travelled in the families, co-learned and orally transmitted. Seining knowledge is condensed into the apaja catch sites (Mustonen 2014a) that can number hundreds around the lake. Catch sites are considered the property of the fishermen.

Species behaviour and TEK of vendace has been linked in literature with ecological and limnological science. The Puruvesi fishery is considered to be a hallmark case of how well TEK can observe, maintain and govern sustainable harvests. This is also reflected in policy and management when fishermen have defended Puruvesi from trawlers, unlike in the greater Längelmävesi area where some fishermen accepted the trawlers at the expense of others. Justification for the denial of trawlers on Puruvesi has been linked to overharvests and wealth accumulating to only a handful of fishermen as opposed to many seiners sharing the results in a more equitable way.

Positioning the observations of changes in bream size and abundance into a dialogue with science from Jukajärvi (Luonnonvarakeskus 2020, Huusari 2020, Yrjölä et al. 2015) shows convergence (Table 3). Bream size is observed to go down while numbers trend up, and they are also understood to advance the eutrophication processes through their feeding patterns. Of special importance is the discovery of brook lamprey in the Kissapuro stream in the Jukajärvi catchment area (Mustonen and Tossavainen 2018) using 'subtle signs'. This is a major indicator species for ecosystem health, and therefore meaningful in surveys of a damaged catchment.

\section{Conclusions and Discussion}

Finnish traditional knowledge of waters has not been officially recognized in the way aquatic ecosystems are known, administered and altered. In this paper we have reviewed three relevant lakes ranging from a small (Jukajärvi) to large in scale (Längelmävesi, Puruvesi). Using key indicators (quality of knowledge, ecosystem observations, weather, species and others) we can determine common elements and also great divergence across Southern Finland along an east to west axis. We also need to understand the simultaneous events and drivers of change affecting boreal lakes today, some of which have been presented in summary form in the adjacent Fig. 5.

Common to all locations is that knowledge is built on regular, sometimes even daily (Puruvesi) observations. Secondly, knowledge that is trusted and shared, whether for research purposes (oral history documentation) or amongst fishermen themselves is built on actually fishing. Harvesting fish (and in some cases crayfish) maintains, renews and provides for the central elements of a traditional knowledge system (Berkes 2008). We focus here on the harvest associated with household or commercial gill netting, seining and fish traps. Sports fishing and associated gear and practice fall outside our current study.

The locations diverge in the timing of observations by fisherman, passing of unbroken communal knowledge and also partly determined by the ecological qualities of past and present. Size of the waterbody also plays a role (Fig. 6).

The individualized TEK from Längelmävesi, as in Kalevi Vierikka's oral histories, can be traced back well into the $1800 \mathrm{~s}$ but has no shared or communal aspect. Kalevis TEK was lost when he died. It cannot be replicated as a "learned" practice in the similar style. Kalevi maintained both a repository of TEK as learned and practiced and importantly also used his knowledge in investigations and confirmation of natural weather and ecosystem events. This approach has yielded important lived knowledge that allowed him also to test and reflect on phenomena 'inside his knowledge'.

Jukajärvi is a story of loss and recovery. Household fishing knowledge proved important in pointing out the impacts of human-induced degradation on the lake (lowering, organic loading, acidic discharges). Mustonen (2013) shows how oral histories were able to detect and convey baselines of a large-scale restoration of a lake. Mustonen and Tossavainen (2018) demonstrate that subtle signs are important and may yield valuable ecosystem data and discoveries when TEK has a safe and understanding context. Of special 
Table 3 Comparative indicators of traditional knowledge in Jukajärvi and Puruvesi

\section{Traditional \\ knowledge \\ indicators}

Elements of Key Currents do not play a large role in the corpus of Water Knowledge

Special Events

Scale of Temporal Observations

Weather

Knowledge and Climate scales 2002. elderly lady remembered the water quality and indicators and backcasting

\section{Jukajärvi}

Like in Längelmävesi the knowledge of change is individualistic, with some of the older oral historians born between 1900 and 1932 referring to more 'communal' practices and knowledge (reflective of social change in Finland)

traditional knowledge here. This is explained by the smaller lake size and observations made by household fishermen that are irregular on both spatial and temporal

Special events emerge from the corpus, including the 1959 lowering of lake Jukajärvi and its ecological and social impacts. Another event worth referral has been a localized hurricane ('trombi') that impacted the lake in

Scale of temporal observations goes back to 1900 s. An associated the water visibility with the laundry practices on the lake. She was 100-years-old at the time of documentation (2012). In Längelmävesi more detailed accounts from 1840 lowering of water and early $1900 \mathrm{~s}$ result from the fact that Kalevi was involved daily in a professional fishery, which created a space for more

Weather and associated climate changes, in addition to the small hurricane, are consistent with the observations from Längelmävesi. Winters became warmer, ice conditions worse, autumns are more unstable. In Jukajärvi people reported a decadal change of more rainy summers between 2000-2012. Use of perch fins for seasonal weather prediction emerge in the materials. Dreams and prophesies in fisheries are referred to but not made explicitly available

\section{Puruvesi}

Puruvesi TEK remains mostly communal, shared and collective as opposed to the individualised knowledge of the Western Finnish professional fishermen and the household fishing knowledge in Jukajärvi. It is re-enacted through especially the winter seining and daily exchanges with the local fishermen. Apaja, the catch sites, are the keystone geographical spatial and temporal marker of oral history and TEK

Currents, the bottom, ice and lake water column qualities are central to success in fishing. Also the daily, weekly and seasonal movements of vendace are crucial to the Puruvesi TEK. GPS has emerged in $2010 \mathrm{~s}$ as an assisting tool to document and navigate on the lake. Observations are made regularly, daily and sometimes on several occasions per day especially during the peak fishery

Knowledge of special events is more decentralized on Puruvesi than in Längelmävesi or Jukajärvi.

This is partly also explained by the rather pristine quality of the lake and accustomed practices. Perhaps most notably the loss of vendace stocks in $1940 \mathrm{~s}$ and in 1970-1980 s and the 'comeback' of vendace from $1990 \mathrm{~s}$ onwards constitute the specially remembered and reflected-on events. Algae blooms and climate change impacts begin to feature in the oral histories from 2010 onwards

Baselines for lake health rest on individual families and the formation of communal knowledge. Records exist since $1300 \mathrm{AD}$ on the harvest so this also diverges from many other lakes where there are no records prior to $1800 \mathrm{~s}$

Traditional weather prediction, deep relations with the lake and interconnected role of for example moon, vendace and spatial distribution of successful harvests as a response is alive and well on Puruvesi. Dreams and deeper relations with the lake exist but are discussed mostly in private. Climate change observations constitute a major set of observations both for the summer (new fog, rain and wind conditions, survival of vendace fry) and especially the winter conditions (lack of ice, unstable and unsafe ice, early break up) 
Table 3 continued

Traditional knowledge indicators

\begin{tabular}{|c|c|c|}
\hline $\begin{array}{l}\text { Species } \\
\text { Distribution, } \\
\text { Variety and } \\
\text { Change }\end{array}$ & $\begin{array}{l}\text { Species distribution, variety and change focus on } \\
\text { Common Bream (Abramis brama) that emerges from } \\
\text { the corpus as a key ecological indicator. Oral histories } \\
\text { convey a seasonal calendar built around bream harvests, } \\
\text { fish being larger and healthier in size before the } 1959 \\
\text { lowering of the lake and continued practice-knowledge } \\
\text { of the spawning locations not visible in modern research } \\
\text { data or surveys of Jukajärvi. This corresponds to } \\
\text { Längelmävesi indicator species of vendace, pikeperch } \\
\text { and smelt when positioned to the size of the lake and the } \\
\text { quality of traditional knowledge documented in the } \\
\text { corpus }\end{array}$ & $\begin{array}{l}\text { Species distribution, abundance and health is } \\
\text { mostly focused on vendace and remains at a high } \\
\text { level. Seasonal, weekly and daily changes in } \\
\text { vendace and the locations of the schools are } \\
\text { central to success in the fishery. Additional } \\
\text { species that are observed include the grayling, } \\
\text { Saimaa seal, yellow perch, whitefish and smelt }\end{array}$ \\
\hline $\begin{array}{l}\text { Linguistic } \\
\text { Diversity }\end{array}$ & $\begin{array}{l}\text { Linguistic diversity emerges primarily through the } \\
\text { documented bream calendar and place names in the } \\
\text { Jukajärvi context, reflective of the Kiihtelysvaara dialect } \\
\text { of Finnish }\end{array}$ & $\begin{array}{l}\text { Linguistic diversity interconnected with aquatic } \\
\text { diversity manifests both through the Kesälahti } \\
\text { and Kerimäki dialects and the hundreds of orally- } \\
\text { known apaja catch sites. These hydronyms are in } \\
\text { some cases dating back to pre-history. The local } \\
\text { classifications of apaja sites that inform what } \\
\text { should be pulled weekly, once a season, or } \\
\text { monthly are some of the examples of the deep } \\
\text { socio-linguistic connections to Puruvesi the } \\
\text { fishermen still maintain }\end{array}$ \\
\hline
\end{tabular}

Summarized from Pennanen 1979, 1986; Mustonen and Mustonen 2013, Mustonen 2013; Pakarinen 2013; Mustonen 2009, 2014a; Huusari 2020

Fig. 6 (For Social Media). Puruvesi Winter Seiners, Winter 2020. Photo: Tero Mustonen, 2020

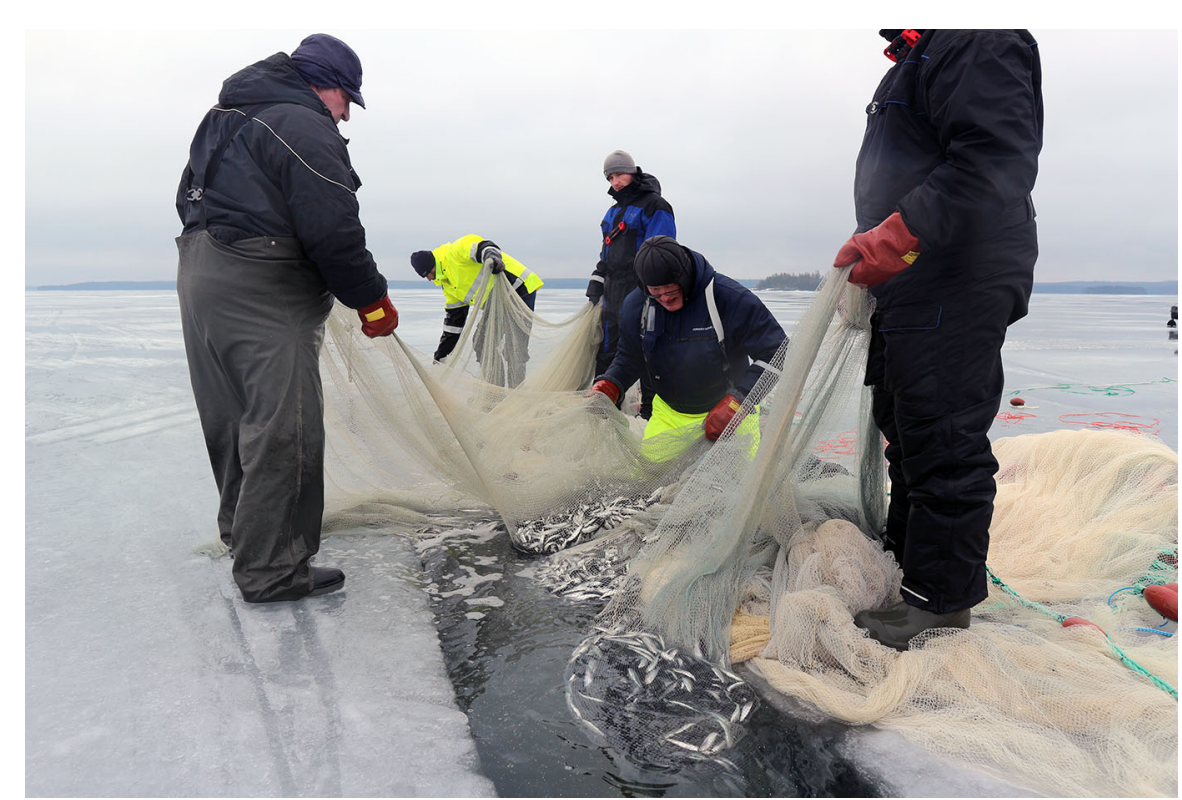


interest are the clear waters of Jukajärvi, which according to local TEK mean highly acidic, disturbed waters as opposed to the generalized indication of good waters (Huusari 2020). Inclusion of a large group of 30 people, extensively interviewed, results in a heterogenous knowledge corpus. It is more suitable for investigations of a wide range of impacts and community based observations (Johnson et al. 2015).

In Puruvesi the seining has remained, shifting and adapting, in place since $1300 \mathrm{AD}$. It represents the last remaining communal knowledge base in fisheries for southern Finland. Vendace movements, relations with the lake, weather prediction, climate change impacts and long-term fish stock shifts are shared amongst the fishermen and co-learned and renewed through every season. The Puruvesi knowledge has been recognized as intangible national heritage demonstrating its value to outside society too. Fishermen know their lake and ice through bodily (Huusari 2020), linguistic (Maffi 2005) and practical relations (Mustonen 2014b). Puruvesi may be considered most system-wide knowledge practice but requires long term engagement and internalisation of presence to interpret and understand the nuances, scales and contexts of change.

In the context of universal value those elements of traditional knowledge that can be determined as endemic (Mustonen 2014a) emerged in all cases, however they are most heterogenous in Jukajärvi due to the texture and divergent purposes of acquiring knowledge as practice (household fishery). Berkes (2008) refers to this as the deep knowledge of ecosystems.

Two examples illustrate the challenges, depth and access in this context. Karmutuuli, a wind that is associated with freeze-up and ice break-up in the local context has taken centuries to develop. It has been named in the local dialect, tested, observed and finally determined within the living knowledge corpus to be a rather accurate marker of seasonal shifts. Vierikka used it to test how weather patterns and conditions have changed and determined that 1997 was still the year when Karmutuuli winds were reliable. Beyond that date changes in the weather superceded the ability of traditional knowledge to make accurate predictions.

A second example will be referred only in passing. Berkes (2008) names this to be an "inner" circle of knowledge especially in human-environmental knowledge. Vierikka, Puruvesi fishermen and Jukajärvi observants all referred to dreams as a source of information. Vierikka recounted events where certain fish and animals could foretell things to come, speaking of an extremely close relationship between humans and their surrounding nature, and indeed the whole cosmos. Most of this sphere is for the internal uses of the families and communities and will not be discussed more here.

Today the Finnish governance of waters relies primarily on expert and scientific knowledge (Bilaletdin et al. 2010; Hölli 2010; Salmi 2000; 2013; Söderholm et al. 2018; Vehanen et al. 2020). Traditional knowledge was belittled (Saiha and Virkkunen 1986) for a long time and created a low self-esteem among the fishermen. Yet, as they knew in the way they knew, many individuals, such as Kalevi Vierikka strived to maintain and excel in their traditional knowledge until $2000 \mathrm{~s}$. Special locations such as Puruvesi were even celebrating and gaining international recognition for their unbroken knowledge as it linked with a sustainable fishery (Huusari 2020).

Today in the context of climate and environmental crises Finnish traditional knowledge of waters, where it can still be found, is a crucial element in conveying messages of positive relations with ecosystems, longterm change, equity issues and more holistic relations to waters as co-living and co-inhabiting (Lehtinen 2012) non-humans. Practical applications are many, from restoration potential (Mustonen 2013) to community-based monitoring (Johnson et al. 2015) using cultural (Harmon 1996) and linguistic (Maffi 2005) indicators. TEK can also provide for more equitable dialogue with science (Gabrys et al. 2016, Turbé et al. 2019) as agency, context and interpretative capacity remain.

However, before we can embark on such a road, we need to start from a (new) beginning. A beginning that acknowledges that waters with their associated lifeforms and humans can co-exist, as they have coexisted for centuries before the large-scale transformation to a modern way of life that has dominated the ways of knowledge over the past century. This beginning is in haste as many people with traditional knowledge can unfortunately often only be heard through recorded voices leaving out the situated wholeness associated with seasoned and nuanced traditional knowledge.

Funding Open access funding provided by University of Eastern Finland (UEF) including Kuopio University Hospital. 
Open Access This article is licensed under a Creative Commons Attribution 4.0 International License, which permits use, sharing, adaptation, distribution and reproduction in any medium or format, as long as you give appropriate credit to the original author(s) and the source, provide a link to the Creative Commons licence, and indicate if changes were made. The images or other third party material in this article are included in the article's Creative Commons licence, unless indicated otherwise in a credit line to the material. If material is not included in the article's Creative Commons licence and your intended use is not permitted by statutory regulation or exceeds the permitted use, you will need to obtain permission directly from the copyright holder. To view a copy of this licence, visit http://creativecommons.org/licenses/by/4.0/.

\section{References}

\section{Traditional Knowledge Sources}

Hakala V (2002) Oral history tape. Available at Snowchange Cooperative Oral History Archives

Huusari N (2020) Kalastajien biokulttuurinen tieto kolmella vesistöalueella. Unpublished MS. thesis. (in print), University of Eastern Finland

Mustonen T, Mustonen K (2013) Jukajoen ja -järven hoitosuunnitelma. Snowchange Cooperative, Kontiolahti

Mustonen T (2009) Karhun väen ajast-aikojen avartuva avara. Unpublished Ph.D. thesis, University of Eastern Finland

Pakarinen R (2013) Puruveden kalastajat. Kerimäki, KirjaPakari

Sairiala H (2002) Oral history tape. Available at Snowchange Cooperative Oral History Archives

Tuominen E (2002) Oral history tape. Available at Snowchange Cooperative Oral History Archives

Vierikka K (2002-2010). Oral History tapes. Available at Snowchange Cooperative Oral History Archives

Virtaranta P (1950) Hämeen kansa muistelee. Helsinki, WSOY

\section{Literature}

Berkes F (2008) Sacred ecology. Routledge, New York

Bilaletdin $\ddot{A}$ et al (2010) Pirkanmaan vesien toimintaohjelma vuoteen 2015. Tampere, ELY-keskus

Cortazzi M (1993) Narrative analysis-social research and educational studies series 12. The Falmer Press, London

Gabrys J et al (2016) Just good enough data: figuring data citizenship through air pollution sensing and data stories. Big Data Soc 3:2. https://doi.org/10.1177/2053951716679677

Harmon D (1996) Losing species, losing languages: connections between biological and linguistic diversity. Southwest J Linguist 15:89-108

Huntington $\mathrm{H}$ et al (2017) How small communities respond to environmental change: patterns from tropical to polar ecosystems. Ecol Soc 22(3):9
Hölli O (2010) Längelmäveden kalastusalueen hoito- ja käyttösuunnitelma vuosille 2011-2016. University of Applied Sciences Turku, Turku

Johnson N et al (2015) The contributions of community-based monitoring and traditional knowledge to Arctic observing networks: reflections on the state of the field. Arctic 68:28-40. https://doi.org/10.14430/arctic4447

Kiiskinen T (2013) Jukajärven valuma-alueen kunnostustarpeen arviointi. Unpublished Restoration Report (In Finnish), Joensuu, 2013

Kolari I (2018) Pirkanmaan kuhajärvien kalastusselvitys. Fisheries Centre Pirkanmaa, Tampere

Lehtinen A (2000) Veden maantiede: Eli mitä tapahtui vedenpaisumuksen jälkeen? Kuopio Elore 7(1)

Lehtinen A (2012) Politics of decoupling: breaks between Indigenous and imported senses of the Nordic North. J Cultural Geogr 29(1):105-123. https://doi.org/10.1080/ 08873631.2012 .655031

Lieblich A et al (1998) Narrative research: reading, analysis and interpretation. Sage, New York

Loh J, Harmon D (2014) Biocultural Diversity: threatened species, endangered languages. Zeist, WWF Netherlands

MacDonald J (2000) The Arctic sky-Inuit astronomy, Star lore and Legend. Royal Ontario Museum, Toronto

Maffi L (2005) Linguistic, cultural and biological diversity. Annu Rev Anthropol 34(1):599-617. https://doi.org/10. 1146/annurev.anthro.34.081804.120437

Mustonen T (2013) Oral histories as a baseline of landscape restoration-Co-management and watershed knowledge in Jukajoki River. Fennia 191:76-91

Mustonen T (2014a) Endemic time-spaces of Finland: aquatic regimes. Fennia 192:120-139

Mustonen T (2014b) Power discourses of fish death: case of linnunsuo peat production. Ambio 43:234-243. https://doi. org/10.1007/s13280-013-0425-3

Mustonen T, Tossavainen T (2018) Brook lampreys of life: towards holistic monitoring of boreal aquatic habitats using 'subtle signs' and oral histories. Rev Fish Biol Fisheries 28:657-665. https://doi.org/10.1007/s11160-018-9527-0

Nunn P, Reid N (2015) Aboriginal memories of inundation of the Australian coast dating for more than 7000 years ago. Aust Geogr 46:11-47. https://doi.org/10.1080/00049182. 2015.1077539

Pennanen J (1979) Muikkuapajilla. Helsinki, SKS

Pennanen J (1986) Talviapajilla. Helsinki, SKS

Pirkanmaan luonto (1987) Pirkanmaan kotiseutusarjan 1. Osa. Tampere, Pirkanmaa

Rontu L et al (2019) Validation of Lake Surface State in HIRLAM v. 7.4. Numerical weather prediction model against In-Situ measurements in Finland. Geosci Model Dev 12:3707-3723. https://doi.org/10.5194/gmd-12-3707-2019

Söderholm K et al (2018) Collaborative planning in adaptative flood risk management under climate change. Water Resour Manag 32:1383-1397. https://doi.org/10.1007/ s11269-017-1875-3

Tikkanen M (2002) Long-term changes in lake and river systems. Fennia 180:31-42

Tossavainen T (2014) Kontiolahden ja Joensuun alueilla sijaitsevan Jukajärven nykytila sekä alustava kunnostus- ja 
hoitotoimien pohdinta: Jukajärven lasku-uoman Jukajoen nykytilan alustava tarkastelu (Restoration Plan for Jukajoki Basin, in Finnish). University of Applied Sciences Karelia, Joensuu

Turbé A et al (2019) Understanding the citizen science landscape for European Environmental Policy: An Assessment And Recommendations. Citizen Sci Theory Pract 4:34. https://doi.org/10.5334/cstp.239

Saiha M, Virkkunen J (1986) Kalastaja ilman merta: Into Sandbergin elämää ja kynänjälkeä. WSOY, Helsinki

Salmi P (2000) Tieto ja valta kalastuksen päätöksenteossaKonflikteista yhteishallintaan? Alue ja ympäristö 29:47-58

Salmi P (2013) Ohjauksesta vuorovaikutukseen-Kalastuksen hallinnan haasteet. Publications of the University of Eastern Finland, Dissertations in Social Sciences and Business Studies No 64. Joensuu, University of Eastern Finland

Tengö $\mathrm{M}$ et al (2014) Connecting diverse knowledge systems for enhanced ecosystem governance-the multiple evidence base approach. Ambio. https://doi.org/10.1007/ s13280-014-0501-3

Wallin P (2018) Ja niin jäi Sarsa näkemään nälkää: Kangasalan Sarsan mullistus 1604: narratiivin tulkintakehityksiä. Unpublished manuscript. https://www.utupub.fi/bitstream/ handle/10024/146351/Wallin_Paula_opinnayte. pdf? sequence $=1 \&$ isAllowed $=\mathrm{y}$

Vehanen T et al (2020) Data collection systems and methodologies for the inland fisheries of Europe. FAO Fisheries and Aquaculture Technical Paper No. 649. Budapest, FAO. https://doi.org/10.4060/ca7993en

Publisher's Note Springer Nature remains neutral with regard to jurisdictional claims in published maps and institutional affiliations. 